\title{
Koulutushankkeen digitaaliset menetelmät maatalousyrittäjien osaamisen lisäämisessä
}

Susanna Lahnamäki-Kivelä, Anne-Mari Malvisto, Jyrki Kataja, Ulla Heinonen

JAMK Biotalousinstituutti, Tuumalantie 17, 43130 Tarvaala, etunimi.sukunimi@jamk.fi

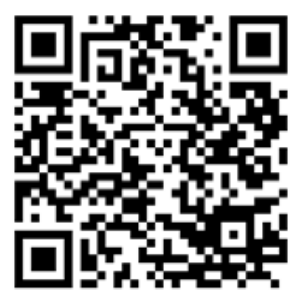

Maatalousyrittäjät, erityisesti kotieläintilalliset, kohtaavat suuren työkuorman ja monimuotoiset velvoitteet työssään. Samaan aikaan osaamisen lisääntymiselle koetaan tarvetta sekä yrityksen johtamisessa että tuotannollisessa osaamisessa. Automaatio on muuttanut maatilojen arkea sitoen viljelijät olemaan tavoitettavissa mahdollisissa ongelmatilanteissa. Tämä johtaa maatalousyrittäjien ajankäytön muutokseen. Koulutushankkeiden toteuttamisessa on nähty pitkään trendi yksittäisten koulutuspäivien kiinnostavuuden laskussa sekä koulutusten painopisteensiirtymisenäsitoutumista vaativiin pienryhmäkoulutuksiin ja erilaisten digitaalisten aineistojen käyttämiseen. Useiden yrittäjien toive ammatilliselle täydennyskoulutukselle on etäyhteyksien hyödyntäminen ja monikanavaisuus. Menestyvä keskisuomalainen nautakarjatila (MEKA) -hanke on Maaseuturahastosta ja Keski-Suomen ELY -keskuksesta rahoituksensa saava koulutushanke, jonka tavoitteena on lisätä maatalousyrittäjien ammatillista osaamista sekä tukea yrittäjien hyvinvointia. Hanke toimii kolmivuotisena vuosien 2015-2018 aikana KeskiSuomen maakunnan alueella. Osana koulutushanketta tuotetaan digitaalista opintomateriaalia, joka on hyödynnettävissä vielä hankkeen päättymisen jälkeen. Materiaalin tuottamisen ohella kerätään kokemuksia sekä materiaalia työstäviltä henkilöiltä että käyttäjiltä. Seurannan kohteena ovat digitaaliset aineistot ja niiden hyödynnettävyys maatalouden ammatillisessa täydennys- ja lisäkoulutuksessa. Digitaalisten aineistojen kokoamisessa hyödynnetään 360॰-kuvaa ja -videota, drone-kuvia ja -videoita, valokuvia, videoita, haastattelumateriaaleja sekä muita digitaalisia aineistoja. Materiaaleja julkaistaan valtakunnallisten sekä alueellisten koulutus- ja kehittämishankkeiden kanssa yhteistyössä, esim. Ravinne- ja energiatehokas maatila (http://ravinnejaenergia.fi/fi/etusivu/) ja https://www.aitomaaseutu.fi. Yhteistyö aineistojen jakelukanavissalaajentaatehdyntyönvaikuttavuuttajaparantaatiedonsaatavuutta.

Asiasanat: koulutus, digitalisaatio, koulutushankkeet 


\section{Johdanto}

Maatalousyrittäjien määrä on vähentynyt ja samaan aikaan koulutustaso toimivilla yrittäjillä on kasvanut. Rakennekehityksen myötä tilojen koko on kasvanut (LUKE 2017) ja tilat sijaitsevat aiempaa harvemmassa. Nämä kehityssuunnat vähentävät yrittäjille järjestettävien koulutusten määrää ja muuttavat koulutuksen muotoja. Kehittyvä tietoliikenneinfra mahdollistaa monipuolisten etäyhteyksien käyttämisen niin koulutuksiin kuin etäseminaareihin osallistumiseen. Erilaisten tapahtumien yhteydessä hyödynnetään yhä enemmän liveseurantaa esimerkiksi Youtube -kanavalla tai verkkoneuvottelu- ohjelmistojen avulla. Kehittyneet kanavat mahdollistavat luotettavamman etäyhteyden eivätkä vaadi normaalia tietoteknistä valmiutta suurempaa osaamista verkkoneuvottelujen yleistyttyä yhteiskunnassa laajemminkin. Etäyhteydet yhdistettynä sosiaalisen median työkaluihin, kuten Twitteriin esimerkiksi ns. some-seinän kautta, mahdollistavat vuorovaikutuksen lisääntymisen ja suuremman tavoitettavuuden asialle. Tämä taas mahdollistaa asiasta käytävän keskustelun laajentumisen ja uusien näkökulmien saamisen käsiteltävään asiaan.

Tallennetut aineistot edesauttavat palaamista aiheen pariin myöhemmin ja tiedonsaannin heillekin, jotka eivät ole voineet osallistua koulutustilaisuuteen paikalla olevina tai etäyhteyksien avulla. Koulutustapahtumien lisäksi on kuitenkin tarvetta myös työnohessa tapahtuvan oppimisen ja tiedonhaun koulutuksellisille materiaaleille, jotka on rakennettu modernien verkko-opetusmetodien mahdollisuuksia hyödyntäen.

Modernit verkko-opetusmetodit tarjoavat some-seinien lisäksi vuorovaikutuksellisia kanavia, joissa fyysisen läsnäolon voi kohtuullisesti korvata hyödyntämällä kannettavaa tietokonetta headsetin kanssa tai koulutuksiin voi osallistua pelkän älypuhelimen kautta. Etäyhteydet helpottavat yrittäjien osallistumista erilaisiin koulutuksiin, kun aikaa toisinaan pitkiinkin siirtymiin ei kulu ja mm. koulutushankkeissa saadaan pienryhmiä kokoon laajemman rekrytointialueen mahdollistamana. Digitaaliset materiaalit ovat kustannustehokas tapa tuoda uutta tietoa esimerkiksi tutkimustoiminnasta heti yrittäjien saataville. Sosiaalisen median kanavat madaltavat kynnystä ottaa yhteyttä itselle vieraisiin henkilöihin ja esimerkiksi seurata erilaisissa sosiaalisen median kanavissa mm. tutkijoita tai toisia yrittäjiä.

Jotta jatkossa osataan varautua riittävän hyvin sähköisten oppimisympäristöjen ja -materiaalien sisällyttämiseen osaksi koulutushanketta, on Menestyvä keskisuomalainen nautakarjatila (MEKA) hankkeessa ryhdytty dokumentoimaan erilaisia tapoja lisätä etäyhteyksiä ja tuottaa koulutushankkeen osana digitaalisia materiaaleja. Hankkeen kuluessa dokumentaatiota jatketaan ja sen rinnalla toteutetaan kyselytutkimus hankkeen osallistujille erilaisten sähköisten kanavien käyttämisestä.

\section{Materiaalit ja menetelmät}

Koulutushankkeen tapahtumissa ja toteutuksissa on kokeiltu erilaisia vaihtoehtoja ja työkaluja toteuttaa sekä koulutuksia verkon ylitse, että tuottaa verkko-opintomateriaalia koulutustapahtumien tueksi. Verkkokoulutuksissa on hyödynnetty Adobe Connect Pro -ohjelmistoa, Skypeä, Webex yhteyttä sekä kahdenvälistä kevyttä videoneuvotteluyhteyttä maito.io.

Itsenäisen opiskelun ja koulutushankkeen tapahtumien tueksi on työstetty erilaisia digitaalisia aineistoja, jotka ovat hankkeen osallistujien saatavilla www.aitomaaseutu.fi -sivulla Menestyvä keskisuomalainen nautakarjatila -hankkeen materiaaleissa.

Koulutushankkeessa kootaan dokumentaatiota kokeilluista digitaalisista aineistoista ja menetelmistä. Tämä dokumentaatio on hankkeen päättymisen jälkeen käytettävissä uusien hankkeiden suunnittelussa. Dokumentaation tueksi opiskelijatyönä teetetään kyselytutkimus, jossa selvitetään hankkeen osallistujien kokemuksia digitaalisista aineistoista ja niiden käytöstä.

Kyselytutkimus lähetetään sähköpostilla kaikille Menestyvä keskisuomalainen nautakarjatila -hankkeen osallistujille, n=370 henkilöä, vuoden 2019 aikana, jolloin hanke päättyy. Kysely laaditaan Webropol-ohjelmalla, joka mahdollistaa kyselyn erilaiset etenemistavat osallistujan 
vastauksista riippuen. Kysely toteutetaan osana Jyväskylän ammattikorkeakoulun agrologi opiskelijoiden koulutusohjelmaa ja harjoitustyönä opiskelijoille.

Digitaalisten materiaalien osalta tehtävä dokumentaatio sisältää seuraavat kuvaukset seuraavista osaalueista: aineiston suunnitteluprosessi, aineiston koostaminen, aineiston mahdollinen jälkikäsittely, aineiston jakelukanava ja vaatimukset jakelukanavalle, käyttäjien kokemukset ja arvioinnit materiaaleista.

\section{Tulokset}

Tulokset ovat toistaiseksi empiirisiä kokemuksia, joiden onnistumisia ja epäonnistumisia on dokumentoitu tulevia käyttötarpeita varten. Dokumentaatio on suoritettu osana koulutushankkeen tapahtumaraportointeja. Dokumentaation avulla saadaan tallennettua kokemukset erityyppisten digitaalisten aineistojen työstämisestä ja niiden parissa työskentelyn vaatimasta osaamisesta ja resurssista. Tuloksia voidaan hyödyntää seuraavien koulutushankkeiden suunnittelussa ja toteuttamisessa, kun mietitään digitaalisten materiaalien hyödyntämistä. Verkkomateriaalien työstämisessä on tärkeää pitää mielessä jo suunnitteluvaiheesta asti materiaalin tavoite, millaista oppimista halutaan tukea ja millä keinoilla (Koli 2008).

Kirjalliseen dokumentaatioon saadaan numeerista dataa verkkosivuilla olevien materiaalien käytöstä ja avatuista dokumenteista. Verkossa olevien materiaalien osalta on myös mahdollista nähdä, kuinka kauan kullakin sivulla on vierailtu ja tästä puolestaan pystytään tekemään johtopäätöksiä eri aineistojen kiinnostavuudesta.

Koulutushankkeen osana toteutettujen digitaalisten materiaalien tuottamisen yhteydessä on havaittu näiden työllistävä vaikutus. Mikäli pedagogiikka ja verkkopedagogiikka eivät ole tuttuja, vievät materiaalien valmisteluun liittyvät työt runsaasti aikaa. Yritä ja erehdy -malli on opettavainen, mutta tehoton tapa tuottaa digitaalisia materiaaleja. Mannisen ja kumppaneiden mukaan (2007, 53) syvällinen oppiminen vaatii paitsi tiedontuottamista opiskelijan saataville, myös sen ymmärtämistä ja soveltamisen osaamista. Sen aikaansaaminen vaatii pelkkien materiaalien tuottamista suunnitelmallisempaa työtä. Voidaankin todeta, että koulutushankkeessa, jonka päätehtävä on toteuttaa erilaisia koulutuksia varsinaisten koulutusmateriaalien ja oppimisympäristöjen tuottamisen sijasta, ei välttämättä parhaat resurssit ole käytössä, mikäli mukana oppimisympäristöjä ja materiaaleja tuottamassa ei ole verkkopedagogiikan osaamista.

Videoneuvotteluyhteyksien hyödyntäminen koulutustoimenpiteissä on tehokasta, mutta on harkittava mitä työkalua käytetään missäkin tilanteessa. Koska koulutuksien kohderyhmänä ovat maatalousyrittäjät, joiden fyysinen sijainti ei aina ole vahvojen internet -yhteyksien äärellä, tulee huomioida käytettävän ohjelmiston kuormitus verkolle sekä laitevaatimukset. Yrittäjillä tulee myös olla osaamista yhteydenottoon ja tarvittaessa oman näytön jakamiseen muille osallistujille. Tästä syystä esimerkiksi pienryhmissä on suotavaa ensimmäisellä kerralla kokoontua samaan paikkaan, jolloin myös toisilleen entuudestaan tuntemattomat pääsevät tutustumaan toisiinsa ja yhteydenpito netin kautta on helpompaa.

Mikäli koulutustilanteessa käytetään kahdenvälistä videoneuvottelua esimerkiksi tilaesittelyn tai peltokierroksen toteuttamiseen, on syytä hyvissä ajoin testata käytettävät laitteet ja ohjelmistot sekä niiden yhteensopivuus, jotta itse koulutustilaisuuden aikana ei kohdata hankaluuksia. Ensimmäisellä kerralla, kun esittelijätilan kanssa testataan laitteita ja ohjelmistoja, kannattaa se tehdä vähintään kolme päivää ennen tilaisuutta. Tällöin laiteajuri- ja ohjelmistopäivityksien tekemiseen ja testaamiseen jää riittävästi aikaa, jos niitä tarvitaan. Kun laitteistot on kerran testattu yhteensopiviksi, riittää normaalisti noin puolta tuntia ennen esityksen alkua suoritettu yhteyksien, ääni- ja kuva-asetusten testaus. 


\section{Johtopäätökset}

Digitalisaatio tuo paljon uusia mahdollisuuksia lisätä tiedon liikkumista ja yrittäjille keinoja oman osaamisen kehittämiseksi. Keinojen tulee olla passiivisen katselemisen sijasta oppimisen oivalluksia tukevia materiaaleja, joissa on myös erilaisia vuorovaikutuksen elementtejä, jotka innostavat osallistujia ottamaan tilaisuuksissa aktiivisen toimijan roolin entistä herkemmin. Erilaiset materiaalit kuten videot, tekstit, $360^{\circ}$-kuvat ja -videot, some-kanavat, verkko-oppimisympäristöt ja videoneuvotteluyhteydet tulee hyödyntää yrittäjien koulutustarpeita ajatellen.

Tehokkaan ja syvällisen oppimisen tueksi näistä kuitenkin tulee rakentaa suunnitelmallisesti kokonaisuus, joka tuottaa lisäarvoa maatalousyrittäjälle. Kokonaisuuden ajantasaisuuden vuoksi on tärkeää tuottaa jatkuvasti uutta materiaalia ja hyödyntää monipuolistuvia verkkopedagogiikan mahdollisuuksia.

Jatkossa digitaalisten materiaalien helppokäyttöisyys lisää niiden kiinnostavuutta ja laajentaa käyttöä. Nykyaikaisen älypuhelin teknologian avulla koulutustilanteiden vuorovaikutus muuttuu oppimistyöksi, joita voi tehdä yhdessä samasta aiheesta kiinnostuneiden kanssa täysin paikasta mutta vain osittain ajasta riippumattomasti.

Monialainen maatalouden ja maatalouden sidosryhmistä koostunut tiimi yhdessä pedagogisen osaamisen kanssa ovat avainasemassa laadukkaiden ja hyödyllisten digitaalisten materiaalien tuottamisessa. Useiden asiantuntijoiden mukaan saaminen koulutusmateriaalin tuottamiseen vaatii erilaisia resursseja, mutta käytännön havainto maatalousyrittäjien osaamisen laajuudesta vaatii myös paljon täydennyskoulutukselta, jota erilaiset koulutus- ja kehittämishankkeet tarjoavat maatalousyrittäjille.

\section{Kirjallisuus}

Koli H. 2008. Verkko-ohjauksen käsikirja. Oy FINN LECTURA Ab. 141 s.

LUKE 2017. Ruoka- ja luonnonvaratilastojen e-kirja 2017. Tilastoja maataloudesta, metsäsektorilta sekä kala- ja riistataloudesta. http://stat.luke.fi/sites/default/files/luke-luobio_81_2017.pdf

Manninen J., Bruman A., Koivunen A., Kuittinen E., Luukannel S., Passi S. \& Särkkä H. 2007. Oppimista tukevat ympäristöt. Johdatus oppimisympäristöajatteluun. Opetushallitus. 155 s. 